\title{
A case of primary small cell carcinoma of the liver that was treated with chemotherapy
}

\author{
Hiroyasu Morikawa Yuji Nakayama - Takako Maeda · Yuji Nadatani · \\ Sawako Kobayashi · Shuji Iwai · Masaru Enomoto · Akihiro Tamori · \\ Hiroki Sakaguchi $\cdot$ Nobuhide Oshitani $\cdot$ Shinzoh Kudoh $\cdot$ Norifumi Kawada
}

Received: 12 May 2008/Accepted: 4 July 2008/Published online: 22 August 2008

(c) The Author(s) 2008. This article is published with open access at Springerlink.com

\begin{abstract}
Primary small cell carcinoma (SSC) of the liver is very rare in Japan and only ten cases have been reported worldwide. We report herein the case of a 77-year-old man with primary SCC of the liver. He had a tumor over $10 \mathrm{~cm}$ in diameter which was localized in the right lobe of the liver and had invaded the right diaphragm. In laboratory tests, high serum levels of lactate dehydrase and neuron-specific enolase were observed. A biopsy specimen showed that the tumor cells were similar in cytology to a pulmonary SCC. The patient was first treated with carboplatin and etoposide according to the therapy protocol for pulmonary SCC and then with a regimen using etoposid and cisplatinum, resulting in an unfavorable outcome. We discuss the clinical course and therapy of extra-pulmonary SCC and review the literature of the cases previously reported.
\end{abstract}

Keywords Small cell carcinoma - Extra-pulmonary small cell carcinoma $\cdot$ Chemotherapy $\cdot$ Carboplatin $\cdot$ Etoposide

H. Morikawa $\cdot$ Y. Nakayama $\cdot$ T. Maeda $\cdot$ S. Kobayashi ·

S. Iwai · M. Enomoto · A. Tamori · H. Sakaguchi ·

N. Kawada (更)

Department of Hepatology, Graduate School of Medicine,

Osaka City University, 1-4-3, Asahimachi, Abeno,

Osaka 545-8585, Japan

e-mail: kawadanori@med.osaka-cu.ac.jp

Y. Nadatani $\cdot$ N. Oshitani

Department of Gastroenterology, Graduate School of Medicine,

Osaka City University, 1-4-3, Asahimachi, Abeno, Osaka

545-8585, Japan

\section{S. Kudoh}

Department of Respiratory Medicine, Graduate School of Medicine, Osaka City University, 1-4-3, Asahimachi, Abeno, Osaka 545-8585, Japan

\section{Introduction}

Small cell carcinoma (SCC) is relatively common and accounts for about $20 \%$ of lung cancer. Chemotherapy, not resection or radiation, is the sole therapy for SCC of the lung, indicating a poor prognosis. Although the majority of SCC are located in lungs, the minority $(2.5-4.1 \%)$ has been reported to be from extrapulmonary organs, including esophagus, thymus, stomach, pancreas, and cervix. Accordingly, these are diagnosed as extrapulmonary SCC (EPSCC). Almost the half of the EPSCC are localized in the gastrointestinal tract. The occurrence of EPSCC in other organs is considered to be rare [1-3]. Chemotherapy is the sole treatment for EPSCC and the regimens usually are similar to those for lung SCC. They include the combination of either etoposide and cisplatinum, or camptothecin and cisplatinum [4, 5].

Primary liver cancers in Japan comprise 94.5\% hepatocellular carcinoma (HCC) and $3.6 \%$ cholangiocellular carcinoma [6]. While no case of EPSCC originating from the liver has been reported from Japan, only ten cases of primary SCC of the liver have been reported worldwide [7-11]. Here, we report a case of primary SCC of the liver that was treated with carboplatin and etoposide.

\section{Case report}

A 77-year-old man was admitted to the Department of Hepatology, Osaka City University Hospital, with a 3-month history of general fatigue, breathlessness, and a high serum lactate dehydrase level. Physical examination revealed a slight tenderness at the right costal region. Abdominal magnetic resonance imaging (MRI) indicated a hepatic mass of $10 \mathrm{~cm}$ in diameter in the right lobe of 
the liver (Fig. 1a) that also showed invasion of the right diaphragm in gallium scintigraphy (Fig. 1b). The results of laboratory tests are shown in Table 1 . In addition to the increase in aspartate transaminase (64 IU/l), alanine aminotransferase $(390 \mathrm{U} / \mathrm{l})$, and lactate dehydrase $(6,480 \mathrm{IU} / \mathrm{l})$, neuron-specific enolase (NSE) increased to $389 \mathrm{U} / \mathrm{ml}$ (normal range, $0-10 \mathrm{U} / \mathrm{ml}$ ). Alpha-fetoprotein increased slightly to $27 \mathrm{ng} / \mathrm{dl}$ (normal range $0-20 \mathrm{ng} / \mathrm{ml}$ ). Hepatitis B surface antigen (HBsAg) and antibodies to hepatitis $\mathrm{C}$ virus (anti-HCV) were negative. Antinuclear antibodies and antimitochondrial antibodies were all negative. Nine years earlier, the patient was diagnosed with prostate cancer and was treated with radiation therapy and chemotherapy. He was a nonsmoker and not obese (body mass index, $25.0 \mathrm{~kg} / \mathrm{m}^{2}$ ).

We performed a target needle biopsy of this liver tumor. The microscopic view of the biopsy specimen stained with hematoxylin and eosin indicated a pathologically small, round cell carcinoma (Fig. 2). Immunohistochemical staining revealed that cytokeratin (multi) (AE1/AE3) and cytokeratin CAM5.2, which represents cytokeratin 1-8/10/ 14/15/16/19, were positive. However, Ki-1, NSE, desmin, and vimentin were negative (Fig. 3). No components of leukemia, HCC, or adenocarcinoma were present.

Chest radiographic examination, chest computed tomographic scan, endoscopy of both the stomach and the colon, and fluorodeoxyglucose positron emission tomography (FDG-PET) were performed to exclude the possibility of metastatic tumor from the lung or other extrahepatic organs. Accumulated absorption of fluorodeoxyglucose was observed in abdominal lymph nodes, as well as in the liver tumors, by the FDG-PET. However, no malignant lesions were detected elsewhere in the body (Fig. 1c). Accordingly, we diagnosed this case as an inoperable primary liver SCC.

We started platinum-based chemotherapy with carboplatin AUC 5 on the first day and etoposide (VP-16) $120 \mathrm{mg} / \mathrm{m}^{2}$ on days $1-3$ per month. We followed up and assessed the effect of the chemotherapy by MRI and FDGPET. The assessment was carried out using the criteria of
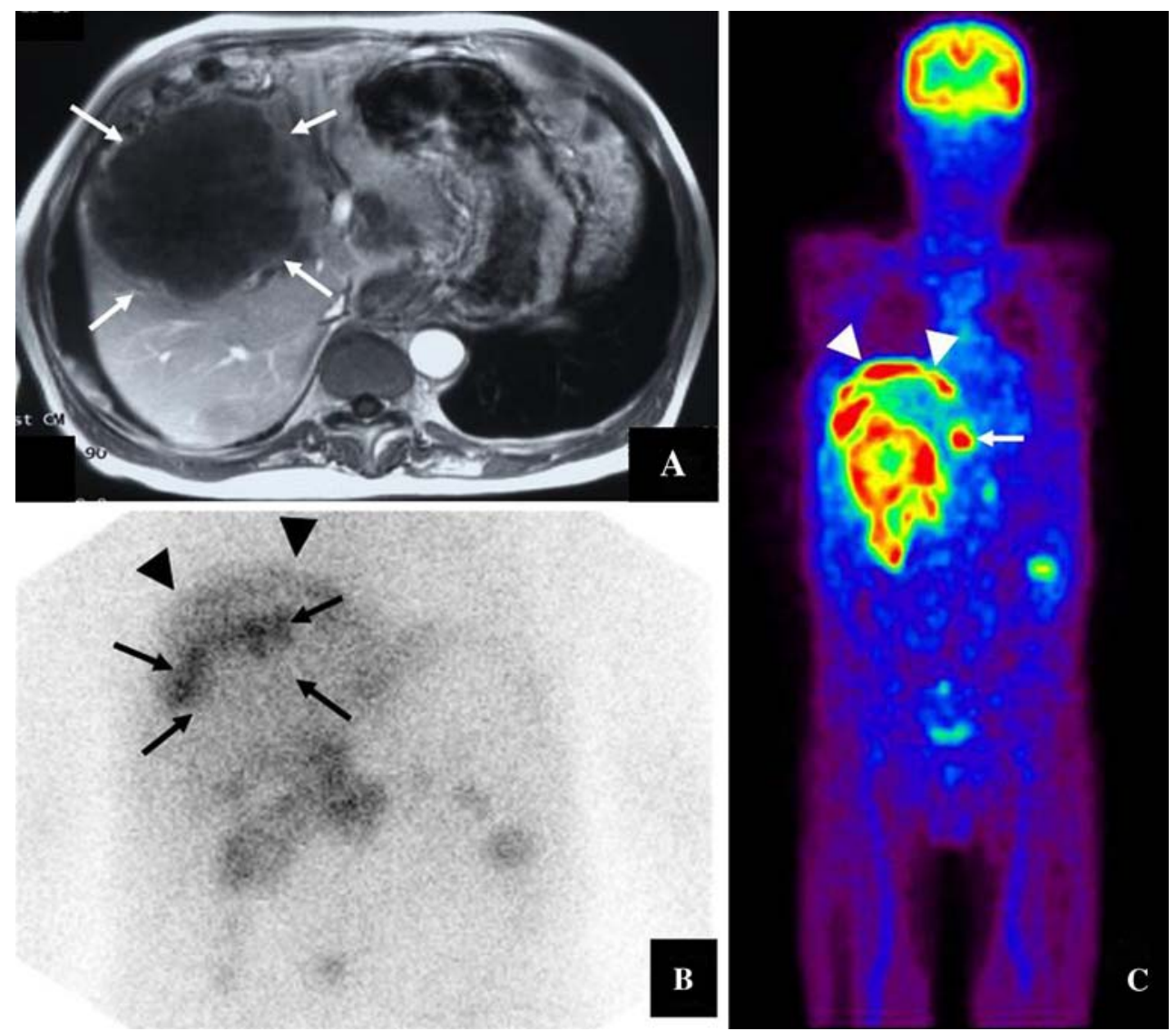

Fig. 1 Image analyses of the liver tumor. (a) MRI indicates a 10-cmsized liver mass with extrahepatic growth in S5/8. (b) Gallium scintigraphy shows the huge mass in the liver (arrows) and its invasion of the right diaphragm (arrowheads). (c) In FDG-PET, accumulated absorption is observed in the liver mass, abdominal lymph nodes (arrow), and the invading tumor in the right diaphragm (arrowheads) 
Table 1 The results of laboratory tests

\begin{tabular}{llllll}
\hline WBC & $3,100 / \mu l$ & BUN & $15 \mathrm{mg} / \mathrm{dl}$ & HBsAg & $(-)$ \\
$\mathrm{RBC}$ & $399 \times 10^{4} / \mu \mathrm{l}$ & $\mathrm{Cre}$ & $0.77 \mathrm{mg} / \mathrm{dl}$ & Anti-HCV & $(-)$ \\
$\mathrm{Hb}$ & $12.1 \mathrm{~g} / \mathrm{dl}$ & $\mathrm{UA}$ & $7.2 \mathrm{mg} / \mathrm{dl}$ & $\mathrm{CEA}$ & $1.8 \mathrm{ng} / \mathrm{ml}$ \\
$\mathrm{Hct}$ & $35.5 \%$ & $\mathrm{Na}$ & $136 \mathrm{mEq} / \mathrm{l}$ & $\mathrm{CA} 19-9$ & $33 \mathrm{U} / \mathrm{ml}$ \\
$\mathrm{PLT}$ & $17.6 \times 10^{4} / \mu \mathrm{l}$ & $\mathrm{K}$ & $3.9 \mathrm{mEq} / \mathrm{l}$ & AFP & $27 \mathrm{ng} / \mathrm{ml}$ \\
$\mathrm{AST}$ & $64 \mathrm{IU} / 1$ & $\mathrm{Cl}$ & $94 \mathrm{mEq} / \mathrm{l}$ & PIVKA-II & $16 \mathrm{mAU} / \mathrm{ml}$ \\
$\mathrm{ALT}$ & $390 \mathrm{IU} / 1$ & FBS & $89 \mathrm{mg} / \mathrm{dl}$ & $\mathrm{NSE}$ & $389 \mathrm{U} / \mathrm{ml}$ \\
$\mathrm{ALP}$ & $390 \mathrm{IU} / 1$ & T-cho & $174 \mathrm{mg} / \mathrm{dl}$ & PSA & $0.418 \mathrm{ng} / \mathrm{mL}$ \\
$\gamma$-GTP & $447 \mathrm{IU} / 1$ & TG & $117 \mathrm{mg} / \mathrm{dl}$ & LD & $6,480 \mathrm{IU} / 1$ \\
LAP & $159 \mathrm{IU} / 1$ & CRP & $2.00 \mathrm{mg} / \mathrm{dl}$ & LDH-1 & $25.2 \%$ \\
ChE & $225 \mathrm{IU} / 1$ & PT & $98 \%$ & LDH-2 & $39.0 \%$ \\
T-Bil & $0.8 \mathrm{mg} / \mathrm{dl}$ & APTT & $31.2 \mathrm{~s}$ & LDH-3 & $24.0 \%$ \\
TP & $6.8 \mathrm{~g} / \mathrm{dl}$ & HPT & $75 \%$ & LDH-4 & $8.8 \%$ \\
ALB & $3.8 \mathrm{~g} / \mathrm{dl}$ & & & LDH-5 & $3.0 \%$ \\
\hline
\end{tabular}

World Health Organization and was indicated as a stable disease. During the therapy, we used granulocyte colonystimulating factor $(150 \mu \mathrm{g} /$ day $)$ for a total of 6 days against the major adverse effects of neutropenia (grade 4, National Cancer Institute-Common Toxicity Criteria). Next, we treated the patient with the second-line chemotherapy regimen using $40 \mathrm{mg}$ of cisplatinum on days $1-3 / \mathrm{month}$ instead of carboplatin. Unfortunately, assessment showed progression of the disease. The performance status (PS) became PS3 using the criteria of the Eastern Cooperative Oncology Group after the second-line therapy and we selected a best supportive care approach according to the patient's wishes. He died about 3 months after admission in our hospital.

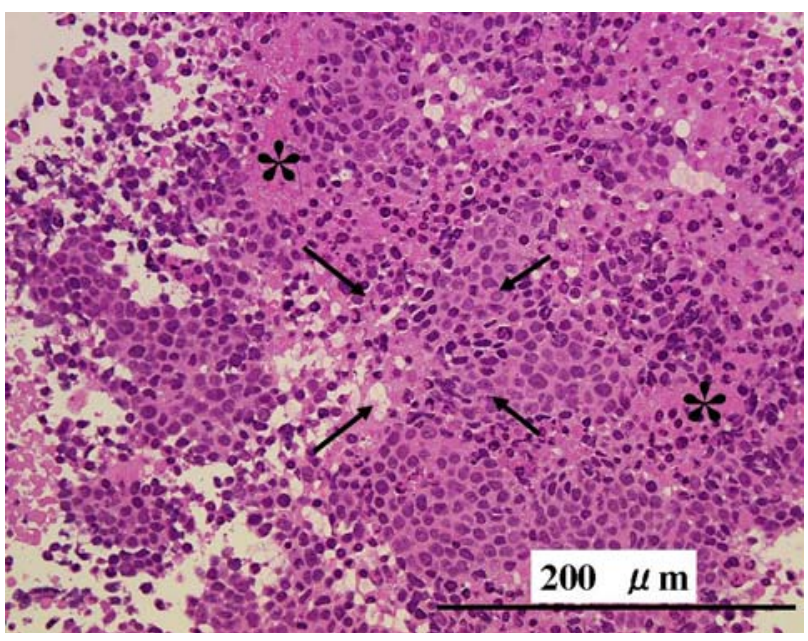

Fig. 2 Hematoxylin and eosin staining of the needle biopsy specimen. Microscopic findings of the tumor reveal the accumulation of small round cells that are similar to SCC of the lung and the presence of cell necrosis (*). The tumor cells show oval to fusiform hyperchromatic nuclei and indistinct nucleoli with frequent mitoses (arrows). Magnification, 400×

\section{Discussion}

EPSCC is a very rare malignant tumor and accounts for about 5\% of all SCC. Duguid and Kennedy [12] first described two cases of mediastinal oat cell tumor in 1930 . Since then, EPSCC has been recognized increasingly as a distinct clinical entity and has been reported in several organs other than the lung over the past 30 years. Primary locations include the head, neck, salivary glands, thyroid, larynx, trachea, thymus, pleura, esophagus, stomach, intestines, rectum, pancreas, gall bladder, cervix, uterus, breast, prostate, urinary bladder, and skin [1-3].

In general, the clinical course of EPSCC is progressive in nature and the tumor often recurs after treatment. Kim et al. [2] analyzed 34 cases, and the median survival of EPSCC in their study was 14 months. In their study, the overall survival of the patients with limited disease was more favorable than those of with extensive disease. EPSCC as a gastrointestinal tumor was especially unfavorable. More than $50 \%$ of patients with limited disease were operated upon or received radiotherapy in combination with chemotherapy for local control, it resulting in differing survival between limited disease and extensive disease [2]. Primary SCC of the liver is very rare and only ten cases have been described in the literature until now (Table 2). In the three cases reported by Zanconati et al. [7], one patient was treated by mass resection but the others received no therapy. The clinical progression was rapid and death ensued between 1 and 5 months after diagnosis. In the two cases reported by Sengoz et al. [8], one patient who received chemotherapy survived for 13 months and the other survived for 67 months after hemihepatectomy. In a case reported by Kim et al. [9], in which segmentectomy of the liver and adjuvant chemotherapy were performed, the patient survived with no signs of recurrence for at least 

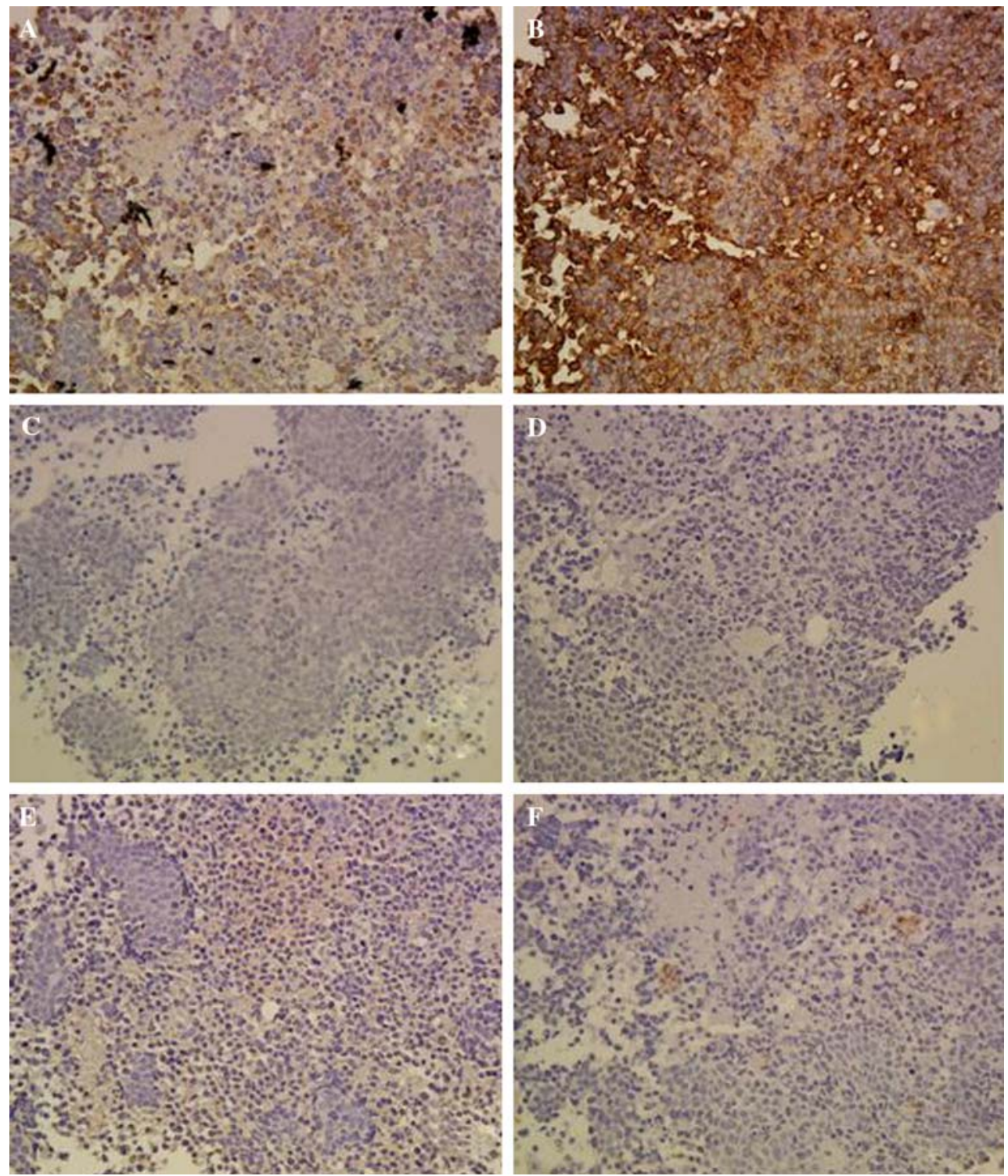

Fig. 3 Immunohistochemical staining of the tumor tissue. The tumor cells are positive for AE1/AE3 (a) and CAM5.2 (b), but are negative for Ki-1 (c), desmin (d), NSE (e), and vimentin (f). Magnification, $100 \times$. AE1/AE3 and CAM5.2 are representative epithelial cell

markers. Desmin and vimentin are nonepithelial and mesenchymal cell markers. Ki-1 is a marker for lymphoma. NSE is a marker of neuroendocrine origin

4 months. In another two reported cases, the patients received continued treatment with combined chemotherapy and survived $[10,11]$. The aforementioned cases of primary SCC of the liver, in which radical operation or combined chemotherapy was performed, had a good prognosis.

The regimens of chemotherapy were similar between lung SCC and EPSCC and consisted of platinum-based combination therapy. In our case, the tumor was diagnosed as an extensive disease because it had invaded the right diaphragm and metastasis to the abdominal lymph nodes was also identified. Accordingly, this tumor was found to be inoperable. Furthermore, on MRI and FDGPET, it showed no response to the cisplatin-based chemotherapy, although the serum level of NSE decreased from $389 \mathrm{U} / \mathrm{ml}$ to $37 \mathrm{U} / \mathrm{ml}$ after the first chemotherapy session.

SCC of the liver was found to express c-kit, a stem cell marker of the liver, in Choi's report [10]. Recently, it has been considered that EPSCC may arise from a multipotential stem cell that is capable of differentiating into SCC. Our and Zanconati's cases were positive for AE1/AE3, being compatible with a carcinoma derived from biliary epithelium, rather than of neuroendocrine origin. 
Table 2 Patients with primary SCC of the liver

\begin{tabular}{|c|c|c|c|c|c|c|c|c|}
\hline Author & Age & Sex & $\begin{array}{l}\text { Stage of } \\
\text { disease }\end{array}$ & $\begin{array}{l}\text { Size } \\
(\mathrm{cm})\end{array}$ & $\begin{array}{l}\text { Positive } \\
\text { immunohistochemical } \\
\text { staining }\end{array}$ & $\begin{array}{l}\text { Negative } \\
\text { immunohistochemical } \\
\text { staining }\end{array}$ & Treatment & $\begin{array}{l}\text { Status/ } \\
\text { survival } \\
\text { (months) }\end{array}$ \\
\hline Ryu et al. & 55 & M & Extensive & 8 & CD56, c-kit, $( \pm)$ SYN & TTF-1 & Chemotherapy & Alive \\
\hline Kim et al. & 53 & M & Extensive & 12 & $\begin{array}{l}\text { CD56, NSE, c-kit, SYN, } \\
\text { mixed CK, EMA }\end{array}$ & $\begin{array}{l}\text { CK7, 8, 19, 20, AFP, CEA, } \\
\text { hepatocyte, vimentin, } \\
\text { desmin, TTF-1 }\end{array}$ & $\begin{array}{l}\text { Segmentectomy, } \\
\text { adjuvant chemotherapy } \\
\text { (cisplatin, etoposide) }\end{array}$ & Alive \\
\hline Zanconati et al. & 56 & M & Limited & 5 & $\begin{array}{l}\text { AE1/AE3, CK8, 18, 19, } \\
\text { NSE, AFP }\end{array}$ & S-100 protein, CEA & No & Dead/1 \\
\hline Zanconati et al. & 69 & M & Extensive & 10 & $\begin{array}{l}\text { AE1/AE3, CK8, 18, 19, } \\
( \pm) \text { NSE, CHR }\end{array}$ & S-100 protein, CEA & No & Dead/1 \\
\hline Zanconati et al. & 89 & M & Extensive & 6 & $\begin{array}{l}\text { AE1/AE3, CK8, 18, 19, } \\
\text { AFP, NSE }\end{array}$ & CHR, S-100 protein, CEA & No & Dead/1 \\
\hline Kim et al. & 67 & M & & 12 & SYN, CD56, c-kit & CK, CEA, AFP & $\begin{array}{l}\text { Chemotherapy } \\
\text { (cisplatin, epirubicin) }\end{array}$ & Alive \\
\hline Sengoz et al. & 73 & $\mathrm{~F}$ & & & & & Right hemihepatectomy & Dead/67 \\
\hline Sengoz et al. & 66 & M & & & & & Chemotherapy (cisplatin) & Dead/13 \\
\hline Kim et al. & & & & & CHR, SYN & & & \\
\hline Choi et al. & 82 & $\mathrm{~F}$ & Extensive & 6.7 & $\begin{array}{l}\text { CD56, NSE, SYN, CHR, } \\
\text { TTF-1, c-kit }\end{array}$ & $\begin{array}{l}\text { Antihepatocyte, AFP, } \\
\text { vimetin, desmin, CK7, 19, } \\
\text { 20, CEA, S-100 protein }\end{array}$ & $\begin{array}{l}\text { Segmentectomy, } \\
\text { chemotherapy } \\
\text { (etoposide) }\end{array}$ & Alive \\
\hline This case & 77 & M & Extensive & 10 & AE1/AE5, CAM5.2 & NSE, desmin, vimentin & $\begin{array}{l}\text { Chemotherapy } \\
\text { (cisplatin, etoposide) }\end{array}$ & Dead/3 \\
\hline
\end{tabular}

AFP, alpha-fetoprotein; CEA, carcinoembryonic antigen; CHR, chromogranin; CK, cytokeratin; EMA, epithelial membrane antigen; NSE, neuron-specific enolase; SYN, synaptophysin; TTF-1, thyroid transcription factor 1

Open Access This article is distributed under the terms of the Creative Commons Attribution Noncommercial License which permits any noncommercial use, distribution, and reproduction in any medium, provided the original author(s) and source are credited.

\section{References}

1. Richardson RL, Weiland LH. Undifferentiated small cell carcinomas in extrapulmonary sites. Semin Oncol 1982;8:484-496

2. Kim KO, Lee HY, Chun SH, Shin SJ, Kim MK, Lee KH, et al. Clinical overview of extrapulmonary small cell carcinoma. J Korean Med Sci 2006;21:833-837

3. Frazier SR, Kaplan PA, Loy TS. The pathology of extrapulmonary small cell carcinoma. Semin Oncol 2007;34:30-38. doi: 10.1053/j.seminoncol.2006.11.017

4. Lo RG, Canzonieri V, Veronesi A, Dal BV, Barzan L, Zancanaro C, et al. Extrapulmonary small cell carcinoma: a single-institution experience and review of the literature. Ann Oncol 1994;5:909-913

5. Galanis E, Frytak S, Lloyd RV. Extrapulmonary small cell carcinoma. Cancer 1997;79:1729-1736. doi:10.1002/(SICI)10970142(19970501)79:9<1729::AID-CNCR14>3.0.CO;2-\#
6. Ikai I, Arii S, Ichida T, Okita K, Omata M, Kojiro M, et al. Report of the 16th follow-up servey of primary liver cancer. The Liver Cancer Study Group of Japan. Hepatol Res 2005;32:163172. doi:10.1016/j.hepres.2005.04.005

7. Zanconati F, Falconieri G, Lamovec J, Zidar A. Small cell carcinoma of the liver: a hitherto unreported variant of hepatocellular carcinoma. Histopathology 1996;29:449-453. doi: 10.1046/j.1365-2559.1996.d01-514.x

8. Sengoz M, Abacioglu U, Salepci T, Eren F, Yumuk F, Turhal S. Extrapulmonary small cell carcinoma: multimodality treatment results. Tumori 2003;89:274-277

9. Kim YH, Kwon R, Jung GJ, Roh MH, Han SY, Kwon HC, et al. Extrapulmonary small-cell carcinoma of the liver. J Hepatobiliary Pancreat Surg 2004;11:333-337. doi:10.1007/s00534-004-0904-9

10. Ryu SH, Han SY, Suh SH, Koo YH, Cho JH, Han SH, et al. A case of primary small cell carcinoma of the liver. Korean J Hepatol 2005;11:289-292

11. Choi UK, Kim JM, Han JY, Ahn SI, Kim JS, Kim L, et al. Extrapulmonary small cell carcinoma of the liver: clinicopathological and immunohistochemical findings. Yonsei Med J 2007; 48:1066-1071

12. Duguid JB, Kennedy AM. Oat-cell tumors of mediastinal glands. J Pathol Bacteriol 1930;33:93-99. doi:10.1002/path.1700330109 